Editorial

\section{Changes and Challenges}

Rüdiger E. Scharf ${ }^{1}$

${ }^{1}$ Division of Experimental and Clinical Hemostasis, Hemotherapy and Transfusion Medicine, and Hemophilia Comprehensive Care Center, Institute of Transplantation Diagnostics and Cell Therapy, Heinrich Heine University Medical Center, Düsseldorf, Germany

Hämostaseologie 2019;39:1-3.

In the past year, several significant changes have occurred to the Journal and its Editorial Board. Most important among these changes is that Schattauer was acquired by Thieme at the end of 2017 and that the Thieme Publishers has become the new partner of Hämostaseologie - Progress in Haemostasis as of January 1, 2018.

\section{Successful Move to Thieme}

Following many years working successfully with Schattauer, both the GTH Council and the Journal's Editorial Board were surprised by the change but ready to accept and address arising challenges. Thieme Publishers under the leadership of Dr. Daniel Schiff, Senior Vice President and Publisher, worked to make the transition from Schattauer to Thieme as smooth as possible. In fact, after a brief changeover period with several inevitable coordination biases between the GTH office and the Thieme editorial office, we now take advantage of a professional publisher's team. Specifically, the input by Graham Brumfield, Associate Publisher, and Dr. Elinor Switzer, Managing Editorial Assistant, is highly appreciated. Elinor is well known to the scientific community by her longstanding and diligent work for Thrombosis and Haemostasis. Her specific editorial experience and her networking activities with referees and authors around the world will be of substantial benefit to Hämostaseologie - Progress in Haemostasis. Following a period in which we had four editorial assistants within 3 years, it is now really appreciated by the Editor and the Editorial Board members to gain stability, continuity, and consistency in following the Journal's objectives as well as the authors' and readers' demands.

\section{Inside the Journal}

As outlined in a previous editorial, it has been a major goal to

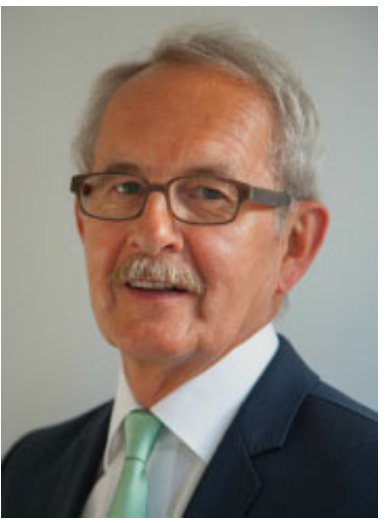

Rüdiger E. Scharf increase the awareness of Hämostaseologie - Progress in Haemostasis among physician-scientists and health professionals and to enhance the attraction of the Journal to our readers. ${ }^{1}$ Using the number of submitted manuscripts as an indicator of the Journal's international awareness, we may conclude that we are approaching this goal. Thus, in 2018, the number of submissions including invited reviews was 120 , reflecting a rise of 71\%, as compared with 70 submissions in 2017. Specifically, the number of submitted original studies $(n=33)$ and case reports $(n=15)$ has increased within the past 12 months. Concomitantly, the number of submissions that had a negative outcome by peer-reviewing ( $n=21)$ has also increased. Currently, the Journal's accept ratio is at $56 \%$. The rate is similar to that reported previously. $^{2}$

Of course, these numbers also reflect a substantial increase in the workload to the Editorial Board (EB), the Advisory Board $(A B)$, and the Editorial Office. On this occasion, I wish to express my gratitude to the $E B$ and $A B$ members for their continued support to the Journal, specifically to those who now are terminating their term. In concert with the GTH Council and the Thieme Publishers, during this year's EB meeting at the GTH Congress in Berlin, we will invite several colleagues to enter the EB either as Section Editor or AB member. A list of those to say farewell and those to be welcomed will be published in the next issue.

\author{
(c) 2019 Georg Thieme Verlag KG \\ Stuttgart · New York \\ received \\ January 17, 2019 \\ accepted after revision \\ January 18, 2019
}

Dttps://doi.org/

Univ.Prof. Dr. Rüdiger E. Scharf,

F.A.H.A., Division of Experimental and Clinical Hemostasis, Hemotherapy and Transfusion Medicine, and Hemophilia Comprehensive Care Center, Institute of Transplantation Diagnostics and Cell Therapy, Heinrich Heine University Medical Center, Düsseldorf, Germany (e-mail: rscharf@uni-duesseldorf.de).
ISSN 0720-9355. 10.1055/s-0039-1678526. 


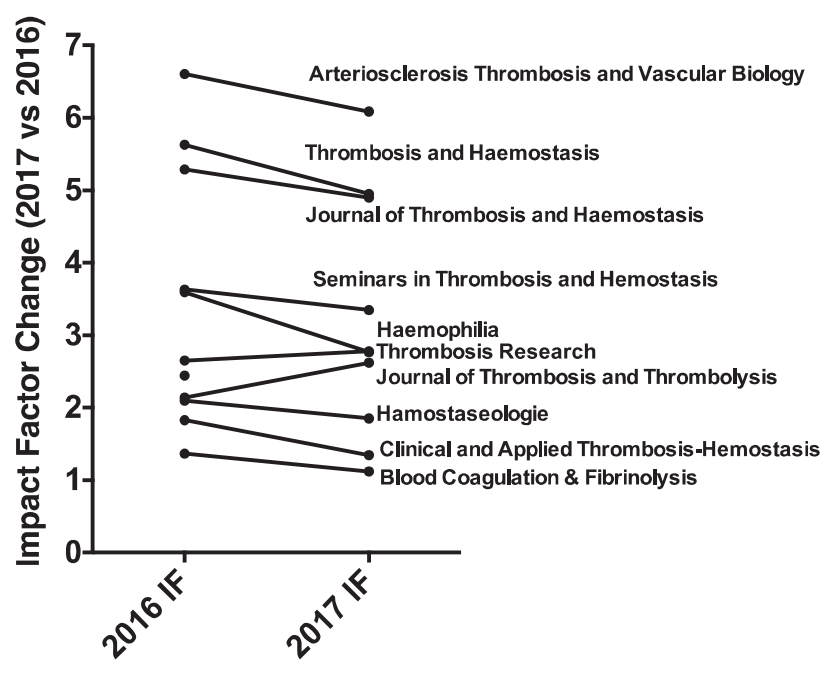

Fig. 1 Change in impact factor 2017 versus 2016. Courtesy of Dr. Emmanuel Favaloro, Editor-in-Chief, Seminars in Thrombosis and Hemostasis (personal communication).

\section{Impact Factor 2017}

Most of the journals in our field experienced a drop in their Impact Factor (IF) for 2017, as did Hämostaseologie - Progress in Haemostasis (-Fig. 1). The current IF is 1.345. The reason for this downward trend may be multi-faceted. One could conjecture that the expansion of competing journals in hemostasis, bleeding disorders and thromboembolic diseases or corresponding publishing platforms, including the plethora of 'open access' journals that are now available and continuing to emerge, is a major cause for the decrease in the IF. However, I believe that this is a too simple explanation or easy excuse, specifically since two journals (Journal of Thrombosis and Thrombolysis; Thrombosis Research) showed a slight increase in their 2017 IF.

Thus, challenges remain. We will continue our efforts to make Hämostaseologie - Progress in Haemostasis more attractive to both authors and readers. This goal can only be achieved by high-quality standards of scientific contributions, instructive educational articles, and regularly updated information about the Society's activities (GTH News). Importantly, a more liberal and consumer friendly access policy by the publisher will be needed to increase the Journal's attraction.

\section{Current Edition}

I am pleased that this year's Presidents of the Annual GTH Meeting have accepted the invitation to become Guest Editors of the Journal's traditional congress issue. Those who have ever been in charge of this role are aware how challenging the task can be to organize a congress, design the scientific program, and edit proceedings. An introduction to the selection of invited congress contributions is given by $\mathbf{D r}$. Robert Klamroth and Dr. Jürgen Koscielny in their editorial focusing on "Science meets clinical practice", the motto of the 63rd Annual GTH Meeting. ${ }^{3}$ I trust that the congress atten- dees will appreciate the opportunity to find take-homemessages already in printed version when arriving at the GTH Meeting.

Moreover, the current issue is supplemented by three articles that have been submitted and accepted after revision during the past year. Those articles are representative of the Journal's mission. In their original work, Carlo Zaninetti et al. ${ }^{4}$ report on novel variants of MYH9-related disorders, comprising a phenotypically heterogeneous group of congenital macrothrombocytopenias that are caused by mutations in the gene for non-muscle myosin heavy (MYH) chain IIA. ${ }^{5,6}$ The authors now report on four novel MYH9 mutations and their corresponding clinical phenotype. $^{4}$

Illustrated by two case reports, Clara Sacco et al. present a clinical update on Lemierre syndrome and propose a protocol for a systematic review and data meta-analysis. ${ }^{7}$ The syndrome, first described in 1936 by André Lemierre as an "anaerobic post-anginal septicemia" 8 , is a rather rare disorder in adolescents or young adults and caused by an acute bacterial infection of the head or neck region (e.g., a tonsillar or pertonsillar abscess). The course is complicated by local vein thrombosis and systemic septic embolism. Since no evidence-based treatment exists so far, the clinical management of Lemierre syndrome is still controversial. This submission prepublished electronically in August 2018 (www. thieme-connect.de) is one of the 10 top articles among the preprint papers that were followed on the publisher's and Journal's Web site.

Acquired hemophilia A (AHA) remains a real 'long runner' of the GTH and this Journal, specifically after the successful GTH-AH 01/2010 study designed, performed and published under the leadership of Andreas Tiede and launched by our Society. ${ }^{9-13}$ In this issue, Renata Pacholczak et al. report on the course in an elderly patient diagnosed with relapsing AHA in whom a hepatocellular carcinoma became evident subsequently. ${ }^{14}$ The authors discuss the association of AHA and malignancy in detail. While case reports are not really popular with editors and journals because of the rather negative effect on impact factors, the present contribution is a good example of how a case report should be, i.e., informative, instructive, and educational.

\section{New Look of the Journal}

The successful move to the Thieme Publishers is reflected by many details. With this issue, we proudly present our novel cover design developed by the publisher's art department. The 'new outfit' and the new layout features match the specific look characteristic of Thieme, a strong brand that is known world-wide for high-quality medical publishing. For each upcoming issue, a cover image will be selected and used as an 'eye catcher' for our readers.

As Editor, I am grateful to the authors, the Editorial and Advisory Board Members and the referees for their work and input, and, last but not least, to our loyal readership. With this editorial, I am extending best wishes to our readers for 2019. 


\section{References}

1 Scharf RE. Awareness and attraction or adhesion and activation. Hämostaseologie 2018;38(01):5-6

2 Scharf RE. Pictures tell their own story. Images in Thrombosis \& Haemostasis Editorial. Hämostaseologie 2017;37(03):181-183

3 Klamroth R, Koscielny J. Science meets clinical practice. The 63rd Annual Meeting of the Society of Thrombosis and Haemostasis Research. Editorial. Hämostaseologie 2019;39(01):4-5

4 Zaninetti C, De Rocco D, Giangregorio T, et al. MYH9-related thrombocytopenia: four novel variants affecting the tail domain of the non-muscle myosin heavy chain IIA associated with a mild clinical evolution of the disorder. Hämostaseologie 2019;39(01):87-94

5 Seri M, Cusano R, Gangarossa S, et al; The May-Heggllin/Fechtner Syndrome Consortium. Mutations in MYH9 result in the MayHegglin anomaly, and Fechtner and Sebastian syndromes. Nat Genet 2000;26(01):103-105

6 Kunishima S, Saito H. Advances in the understanding of MYH9 disorders. Curr Opin Hematol 2010;17(05):405-410

7 Sacco C, Zane F, Granziera S, et al. Barco S on behalf of the Lemierre Study Group. Lemierre syndrome: clinical update and protocol for a systemic review and individual patient data meta-analysis. Hämostaseologie 2019;39(01):76-86
8 Lemierre A. On certain septicaemias due to anaerobic organisms. Lancet 1936;1:701-703

9 Gheisari R, Bomke B, Hoffmann T, Scharf RE. Clinical features and outcome of acquired haemophilia A. Interim analysis of the Düsseldorf study. Hämostaseologie 2010;30(03):156-161

10 Tiede A, Klamroth R, Scharf RE, et al. Prognostic factors for remission of and survival in acquired hemophilia A (AHA): results from the GTH-AH 01/2010 study. Blood 2015;125(07): 1091-1097

11 Tiede A, Scharf RE, Dobbelstein C, Werwitzke S. Management of acquired haemophilia A. Hämostaseologie 2015;35(04):311-318

12 Tiede A, Hofbauer CJ, Werwitzke S, et al. Anti-factor VIII IgA as a potential marker of poor prognosis in acquired hemophilia A: results from the GTH-AH 01/2010 study. Blood 2016;127(19): 2289-2297

13 Werwitzke S, Geisen U, Nowak-Göttl U, et al. Diagnostic and prognostic value of factor VIII binding antibodies in acquired hemophilia A: data from the GTH-AH 01/2010 study. J Thromb Haemost 2016;14(05):940-947

14 Pacholczak R, Bazan-Socha S, Zdziarska J, et al. Acquired haemophilia A associated with subsequent hepatocellular carcinoma. Hämostaseologie 2019;39(01):95-99 